\title{
構造物モニタリングのための画像計測法の研究
}

\author{
廣田彰久 1 - 西山 哲 2 - 菊地 輝行 3 \\ 1 学生会員 博士前期課程 岡山大学大学院環境生命科学研究科（干700-0087 岡山市北区津島中 3-1-1） \\ E-mail:pxhy5vnf@s.okayama-u.ac.jp \\ 2 正会員 岡山大学教授 岡山大学大学院環境生命科学研究科（三 700-0087 岡山市北区津島中 3-1-1） \\ E-mail:nishiyama.satoshi@ okayama-u.ac.jp \\ 3 非会員 (株)開発設計コンサルタント＼cjkstart地質部（†101-0021 東京都千代田区外神田 2-16-2） \\ E-mail:kikuchi-t@jpde.co.jp
}

\begin{abstract}
本研究は，コンクリート構造物に発生したひびわれの幅をモニタリングする技術として画像計測を適用 したものである。まず，反射ターゲットを計測機器として計測点に設置する。 そして，任意の位置から 1 枚の画像に反射ターゲットとひびわれを写し，ひびわれ幅の変位を計算する。本研究では，撮影距離，撮 影角度と計測精度の関係性について実験から検証を行った。 その結果, 撮影距離 $100 \mathrm{~m}$ まで, 撮影角度 $30^{\circ}$ 以内でひびわれの $0.1 \mathrm{~mm}$ の幅の変化を計測できることを確認した。 さらに実際の現場に適用しひびわ れの計測を行うことによって構造物の劣化進行状況を把握し，モニタリング技術への実用性を示した.
\end{abstract}

Key Words: digital photogrammetry, image processing, crack width, maintenance

\section{1. 序論}

高度経済成長期の短期間に社会資本が整備され，数多 くの土木構造物が建設されたが，近年これらの多くは建 設後 50 年以上経過し老朽化している.このような土木 構造物は, 今後 20 年間でさらに増加すると予想されて いる. また，我が国では人口減少が問題となっており， 社会資本維持に関わる財源の確保が今後困難となってく る地域が生じることが懸念される 1)。その上，熟練技術 者も減少しつつあるということが現在の状況である。こ のような状況において, 適切な点検, 維持管理を行って いくことは，ますます重要な課題となっている.

コンクリート構造物において, 維持管理に関わる計測 項目は多岐にわたるが，我々が最初に得られる劣化の情 報はひびわれである．維持管理上，ひびわれ状況を把握 し，構造物の健全性を評価し，以後の補修，補強の計画 を立てることがきわめて重要である 2). またひびわれの 計測項目には, 長さや本数, 幅など多くの項目がある. その中でひびわれの “幅”の計測は，高精度での定量化 が求められ，その手法としては，クラックスケールや， ギス等を用いて直接計測を行う場合や，クラックゲージ 等を計測個所に設置する ${ }^{3}$ ことで計測を行う場合などが ある.これらの手法を用いて随時計測することで，ひび われ幅の変位を調査している. しかし，これらの計測手
法は計測精度が技術者の経験的な判断に依存してしまう

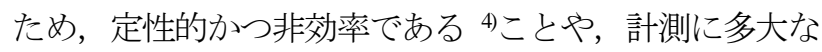
労力やコストを要することなど課題は多い5.，一方で, 進行性の有無やひびわれ幅の変位量に応じてひびわれ対 策工法の選定がなされている のことから，維持管理にお けるひびわれの幅の変位量を把握することが重要である. このような背景から本研究では, コンクリート構造物 の維持管理において重要となるひびわれの進行性に着目 し，写真撮影という簡易作業により，ひびわれ幅の経時 変化を計測する手法の開発を，構造物のひびわれモニ夕 リングに適用するために行ってきた 》。本計測手法は単 写真測量の一種であり, 任意の撮影位置より撮影した 1 枚のデジタル画像を用いて計測を行う. 本手法の特徴と しては，以下のようなことが挙げられる.

1)写真撮影という簡便な方法で計測が可能であることか ら技術の導入が容易にできる点

2)計測機器は基本的にデジタルカメラとパソコンである ことから，低コストで計測を実施できる点 8

本計測手法は，画像上のひびわれ変位を計測するもの である，そのため，反射ターゲットをひびわれ両側に基 準尺として2枚設置する. そして任意の撮影位置から夕 一ゲットを写しこむようにして 1 枚撮影し, 得られた画 像上のターゲットの 2 次元重心座標を求めることでひび われの 2 方向（開口方向とせん断方向）の変位量を計測 


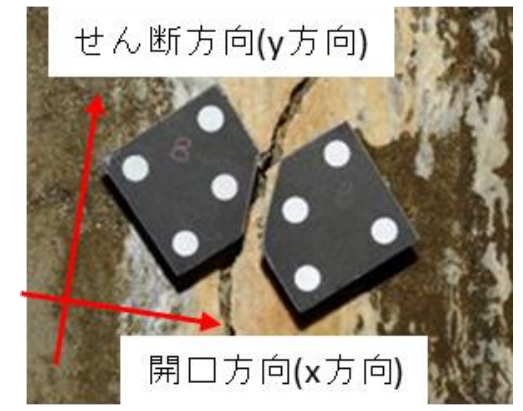

図-1＼cjkstart計測点に設置した反射ターゲット

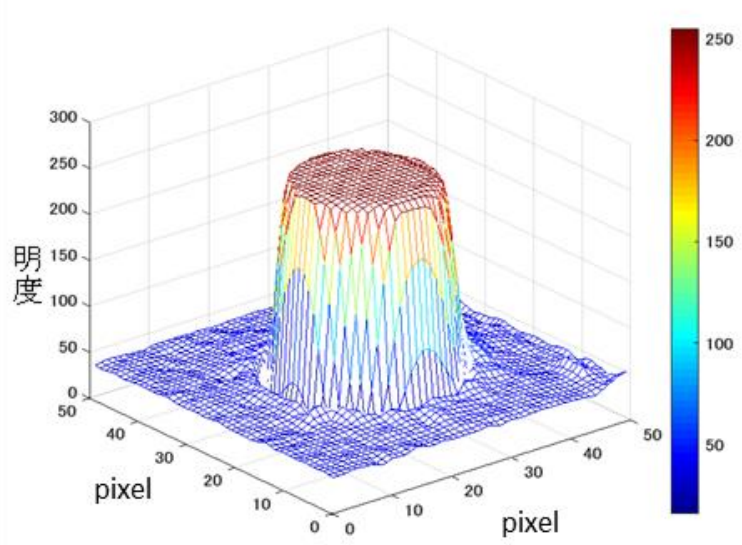

図-2 明度分布の一例

する．本研究では，実際のコンクリート構造物のひびわ れの変位量を計測する手法として適用するために, 計測 精度に影響を与えると考えられるパラメータに関して検 証を行った．具体的には，撮影距離および撮影角度が大 きくなることにより画像上のターゲットが小さくなるこ とから, ターゲットサイズやレンズの焦点距離を変更し, 計測精度の低下について検証を行った。 なお，開口方向 （x 方向）はひびわれの幅に関わる方向，せん断方向 （y方向）はひびわれのずれに関わる方向で定義する.

\section{2. ひびわれ計測における理論}

本章では，本計測手法の手順および計測における基本 理論について記述する. 本計測手法では, 反射ターゲッ 卜を 2 枚一組で計測対象点に設置する. 設置の際は，接 着剂等の利用, あるいは漏水対策のためにアンカー等で 浮かせる方法を用いる. ターゲット設置の向きは計測対 象とするひびわれに対して直交するように設置する．こ の反射ターゲットはガラス製で，トンネル等の暗い状況 下においても計測を可能とするために，カメラのフラッ シュ光に対して強く再帰反射するように作製されている. さらに, 污れの付着を防ぐため, ターゲット表面に加工 処理を施している. ターゲット上の 4 点の白円は正確な

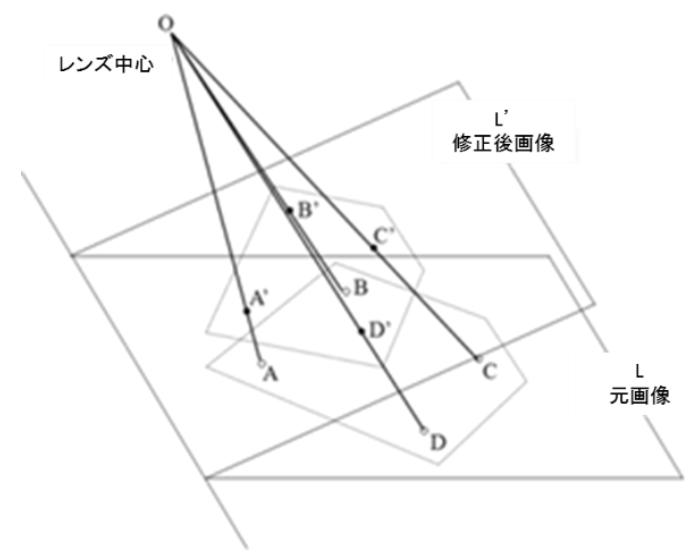

図-3 射影変換の概念

間隔で配置されており，基準尺としての役割の他，後述 する射影変換の既知座標としても用いられる，ひびわれ の変位量を計測し，その進行性について評価する。

\section{(1) 計測手順}

本計測手法の手順を以下に示寸.

1)図-1 に示寸ような反射ターゲットを計測対象となるひ びわれの両側に設置し，任意の撮影位置から反射ター ゲットを写しこむようにして撮影する。はじめに，一 方のターゲット上の 4 点の円の重心の 2 次元座標を算 出する.

2)射影変換技術を用いて，任意の撮影位置から撮影した 画像を正対した位置から撮影した画像に変換する.

3)変換後の画像を用いて，ひびわれ両側のターゲットの 円の 2 次元重心座標を算出する.

4)算出された 2 点の円の 2 次元重心座標を計算し, 前回 計測時の距離からの差分をとることにより，ひびわれ 開口方向と，せん断方向の変位量を評価する.

\section{(2) 基本理論}

デジタル画像計測において高精度で計測を実施するに は, 唯一の観測值となるターゲット円の 2 次元重心座標 の読み取り精度をいかに高めるかが重要である 9. ター ゲット円の 2 次元重心座標は, 図-2に示寸ような明度分 布より計算を行う。明度は 1 画素あたり 0 ２55 までの 256 階調で数值化されており, 本計測手法では, 最低明 度の閯值を定め, 闇值以下の明度については 0 とし，閾 值以上の明度をもつ画素については以下の式を適用して, 明度を重みとした重心計算を実施する ${ }^{10}$.

$$
\begin{aligned}
& x=x_{0}+a_{x} \frac{\sum_{i=1}^{n} \sum_{j=1}^{m}\left(q(i, j) \times x_{i j}\right)}{\sum_{i=1}^{n} \sum_{j=1}^{m} q(i, j)} \\
& y=y_{0}+a_{y} \frac{\sum_{i=1}^{n} \sum_{j=1}^{m}\left(q(i, j) \times y_{i j}\right)}{\sum_{i=1}^{n} \sum_{j=1}^{m} q(i, j)}
\end{aligned}
$$

ここで，( $\left(x_{0}, y_{0}\right)$ は重心計算範囲の原点，( $\left(a_{x}, a_{y}\right)$ はそれぞれ の画素サイズ， $\mathrm{q}(i \mathrm{i})$ )は画素(ij)の明度である. また $x_{i j}$, 


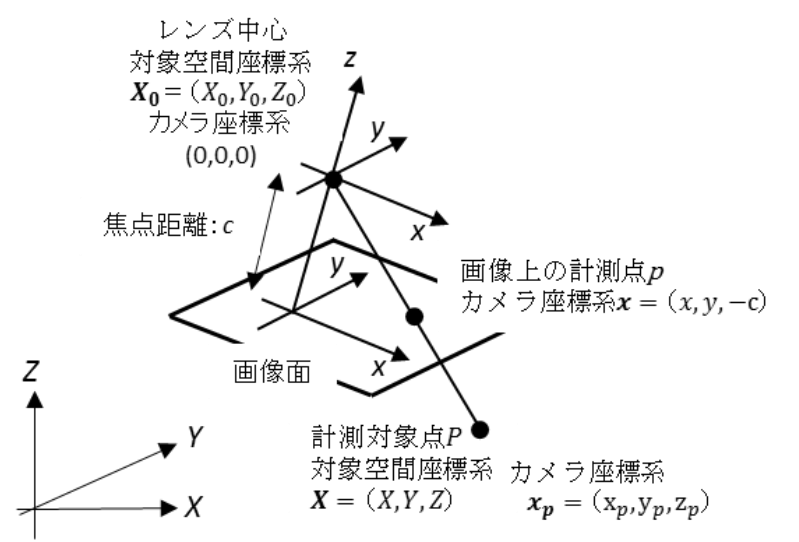

図-4 共線条件の概念

$y_{i j}$ は画素 $(i, j)$ での $x$ 座標およびy座標である.

その後，射影変換技術を用いて元画像を修正，正対化

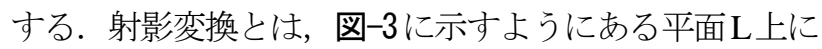
ある点 $(x, y)$ を他の平面上 $\mathrm{L}^{\prime}$ 上の点 $\left(x^{\prime}, y^{\prime}\right)$ に投影されるよう な変換を表す。本計測では，「斜めから撮影された画像 を正対した画像に直す」技術を指す．射影変換は，写真 測量の基本原理である共線条件に基礎をおいており，空 間対象点，その画像上の点，およびカメラの原点，すな わちレンズの中心は，図-4 に示すような幾何学的な関 係を持っている．ここでは，像の反転をなくすため，画 像面は空間対象点側に描いている，対象空間座標系で表 現した計測対象点 $\mathbf{X}(X, Y, Z)$ から発生した光はレンズ中心 であるカメラ座標系の原点を通る. そして画像面上に像 $\mathrm{p}$ を作る.これら 3 点は一直線上に存在する.このとき， 計測点 $\mathrm{P}$ における座標 $\boldsymbol{x}_{\boldsymbol{p}}\left(x_{p}, y_{p}, z_{p}\right)$ および画像上の計測点 $\mathrm{p}$ における座標 $\boldsymbol{x}(x, y,-c)$ はその幾何学的関係から次のよう な式で表せる.

$$
\boldsymbol{x}=-\frac{\mathrm{c}}{z_{p}} \boldsymbol{x}_{\boldsymbol{p}}
$$

ここで， $c$ はカメラレンズの焦点距離を表す.このよう な関係は $y$ 座標, $z$ 座標においても成り立つ. 次に, 力 メラ座標系と対象空間座標系の関係性について述べる. カメラ座標系での点 $\boldsymbol{x}_{\boldsymbol{p}}$ と対象空間座標系での点 $\boldsymbol{X}$ は, 座標軸の回転を表す行列 $\boldsymbol{M}$ とレンズ中心を対象空間座標 系で表した座標 $\boldsymbol{X}_{\mathbf{0}}$ を用いて次のような式で表すことが できる。

$$
M x_{p}=X-X_{0}
$$

ここで，Mは回転行列であり，座標軸の回転は次のよう

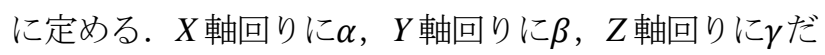
けそれぞれ右回りに回転させるものとする.

$$
\begin{aligned}
& \boldsymbol{M}=\left(\begin{array}{ccc}
\cos \beta & 0 & \sin \beta \\
0 & 1 & 0 \\
-\sin \beta & 0 & \cos \beta
\end{array}\right)\left(\begin{array}{ccc}
1 & 0 & 0 \\
0 & \cos \alpha & -\sin \alpha \\
0 & \sin \alpha & \cos \alpha
\end{array}\right) \\
& \left(\begin{array}{ccc}
\cos \gamma & -\sin \gamma & 0 \\
\sin \gamma & \cos \gamma & 0 \\
0 & 0 & 1
\end{array}\right)
\end{aligned}
$$

この回転行列 $\boldsymbol{M}$ は直交行列であるから，次のように式変

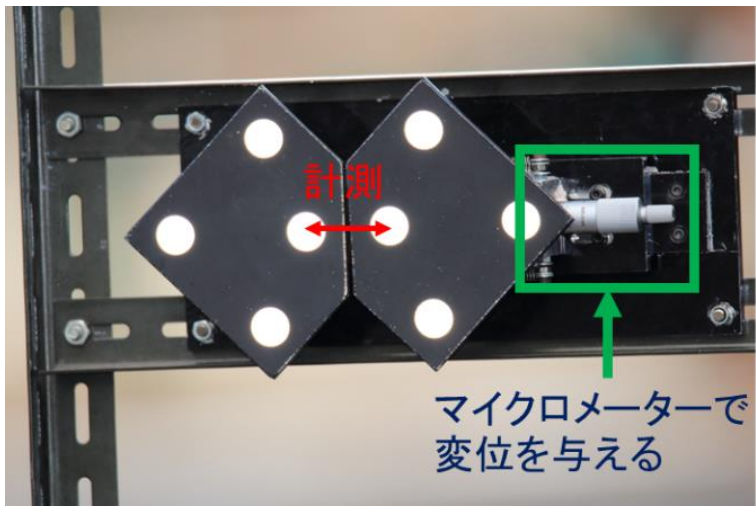

図-5 実験装置の概要

形することができる.

$$
\boldsymbol{x}=-\frac{\mathrm{c}}{z_{p}} \boldsymbol{M}^{t}\left(\boldsymbol{X}-\boldsymbol{X}_{\mathbf{0}}\right)
$$

この回転行列の転置行列 $\boldsymbol{M}^{\boldsymbol{t}}$ の成分を $m_{i j}$ とすれば，成分 で書き下した式(7)および式(8)で表すことができる.

$$
\begin{aligned}
& x \\
& =-c \frac{m_{11}\left(X-X_{0}\right)+m_{12}\left(Y-Y_{0}\right)+m_{13}\left(Z-Z_{0}\right)}{m_{31}\left(X-X_{0}\right)+m_{32}\left(Y-Y_{0}\right)+m_{33}\left(Z-Z_{0}\right)} \\
& y \\
& =-c \frac{m_{21}\left(X-X_{0}\right)+m_{22}\left(Y-Y_{0}\right)+m_{23}\left(Z-Z_{0}\right)}{m_{31}\left(X-X_{0}\right)+m_{32}\left(Y-Y_{0}\right)+m_{33}\left(Z-Z_{0}\right)}
\end{aligned}
$$

以上の式において，測定対象面が同一平面上にあると仮 定することにより，式(9)および式(10)のような 2 次元射 影変換式が得られる ${ }^{11)}$.

$$
\begin{gathered}
X=\frac{h_{1} x+h_{2} y+h_{3}}{h_{7} x+h_{8} y+1} \\
Y=\frac{h_{4} x+h_{5} y+h_{6}}{h_{7} x+h_{8} y+1}
\end{gathered}
$$

この射影変換式には 8 つの未知係数が存在し, それらに 対して 4 点の基準点の測定值の組 $\left(x_{i}, y_{i}\right)(i=1 \sim 4)$ と変 換後の座標 $\left(X_{i}, Y_{i}\right)(i=1 \sim 4)$ から連立方程式を立てて, それを解くことにより求められる. 本研究では, ターゲ ットには4つの真円が正確な間隔で配置されている.

そして最後にひびわれの両側のターゲット円の 2 次元 重心座標より図-5に示す 2 円の重心間距離を計算し，そ の距離の変化によりひびわれの開口・せん断方向の変位 量を評価する.

\section{3. 本計測手法の精度検証}

本計測手法の計測精度を室内実験により，明らかにし た. 本章では精度検証の室内実験の結果について記述す る.

\section{(1) 実験の概要}

先述したとおり, 本計測手法の計測精度は, ターゲッ 


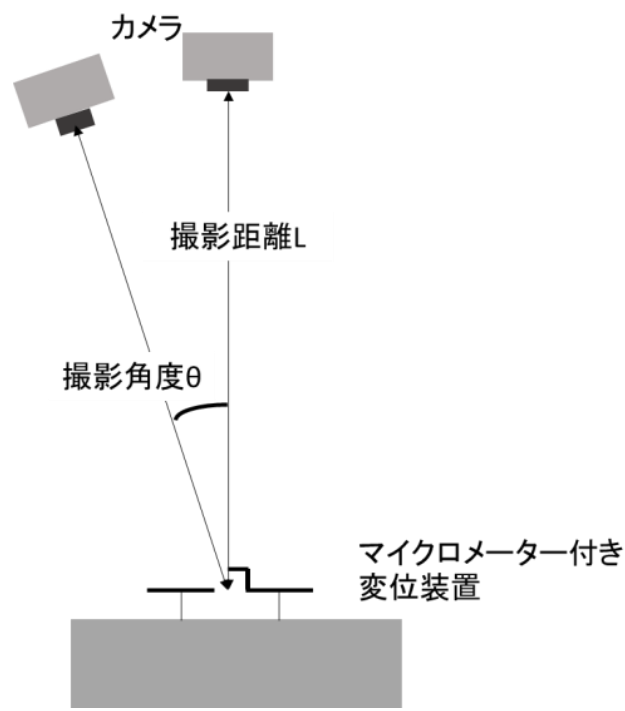

図一～撮影距離と撮影角度の定義

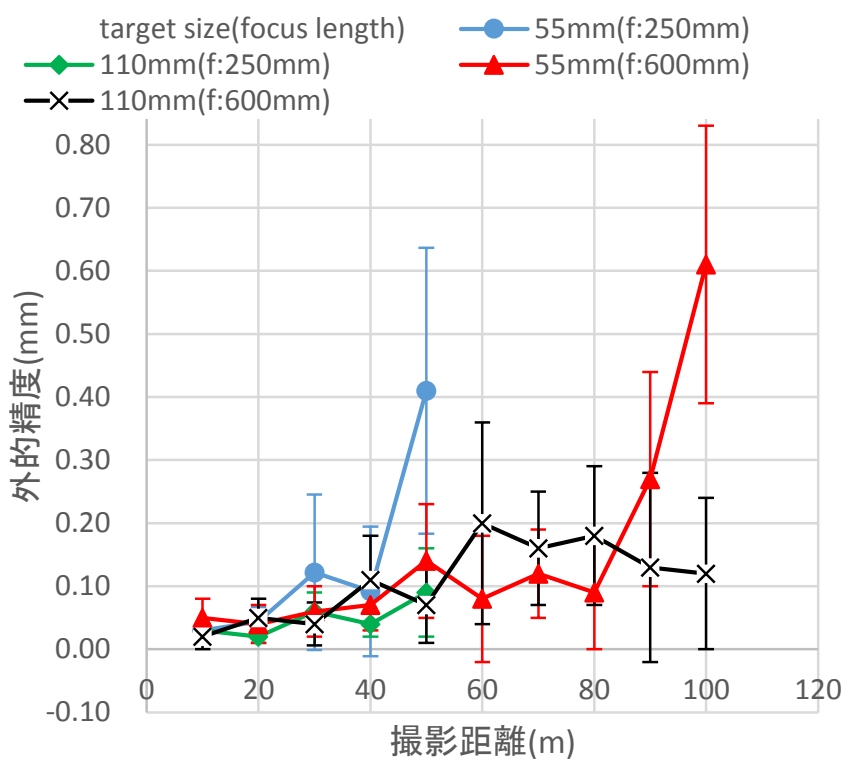

図-7 撮影距離と外的精度

ト円の重心の読み取り精度に強く依存する．重心座標の 読み取り精度は画像上の円の半径と相関があり ${ }^{12}$ ，画像 上の円の半径は撮影距離が大きくなるにつれて，小さく なる．また，撮影角度が大きくなると計測精度は低下寸 る. よって本研究では，撮影距離，撮影角度と計測精度 の関係性について実験より検証を実施した.

実験方法は次のとおりである. 図-5に示すように2枚 の反射ターゲットのうち，1枚を固定し，もう 1 枚をマ イクロメーターを用いて初期值取りをした後，1.0mmま で $0.2 \mathrm{~mm}$ 単位で強制変位させる. また，撮影距離，撮影 角度は図-6 に示すように定義した。撮影距離は 10〜

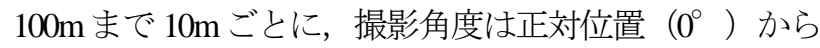

表-1２50mm レンズにおける撮影角度別の計測精度

\begin{tabular}{|c|l|l|l|l|l|l|}
\hline 撮影距離(m) & 撮影角度 & $0^{\circ}$ & $15^{\circ}$ & $30^{\circ}$ & $45^{\circ}$ & $60^{\circ}$ \\
\hline \multirow{2}{*}{$10 \mathrm{~m}$} & 外的精度 $(\mathrm{mm})$ & 0.03 & 0.03 & 0.02 & 0.03 & 0.02 \\
\cline { 2 - 7 } & 内的精度 $(\mathrm{mm})$ & 0.01 & 0.01 & 0.01 & 0.01 & 0.01 \\
\hline \multirow{2}{*}{$30 \mathrm{~m}$} & 外的精度 $(\mathrm{mm})$ & 0.06 & 0.06 & 0.07 & 0.10 & 0.18 \\
\cline { 2 - 7 } & 内的精度 $(\mathrm{mm})$ & 0.03 & 0.05 & 0.08 & 0.08 & 0.16 \\
\hline \multirow{2}{*}{$50 \mathrm{~m}$} & 外的精度 $(\mathrm{mm})$ & 0.09 & 0.24 & 0.48 & 0.2 & 1.47 \\
\cline { 2 - 7 } & 内的精度 $(\mathrm{mm})$ & 0.07 & 0.17 & 0.36 & 0.18 & 0.35 \\
\hline
\end{tabular}

表-2 600mm レンズにおける撮影角度別の計測精度

\begin{tabular}{|c|l|l|l|l|l|l|}
\hline 撮影距離(m) & 撮影角度 & $0^{\circ}$ & $15^{\circ}$ & $30^{\circ}$ & $45^{\circ}$ & $60^{\circ}$ \\
\hline \multirow{2}{*}{$10 \mathrm{~m}$} & 外的精度 $(\mathrm{mm})$ & 0.02 & 0.01 & 0.01 & 0.01 & 0.06 \\
\cline { 2 - 7 } & 内的精度 $(\mathrm{mm})$ & 0.02 & 0.01 & 0.00 & 0.00 & 0.03 \\
\hline \multirow{3}{*}{$30 \mathrm{~m}$} & 外的精度 $(\mathrm{mm})$ & 0.04 & 0.06 & 0.01 & 0.26 & 0.25 \\
\cline { 2 - 7 } & 内的精度 $(\mathrm{mm})$ & 0.03 & 0.01 & 0.01 & 0.03 & 0.13 \\
\hline \multirow{2}{*}{$50 \mathrm{~m}$} & 外的精度 $(\mathrm{mm})$ & 0.07 & 0.05 & 0.04 & 0.10 & 0.20 \\
\cline { 2 - 7 } & 内的精度 $(\mathrm{mm})$ & 0.06 & 0.03 & 0.03 & 0.06 & 0.10 \\
\hline \multirow{2}{*}{$100 \mathrm{~m}$} & 外的精度 $(\mathrm{mm})$ & 0.12 & 0.27 & 0.16 & 0.30 & 0.31 \\
\cline { 2 - 7 } & 内的精度 $(\mathrm{mm})$ & 0.12 & 0.09 & 0.08 & 0.25 & 0.22 \\
\hline
\end{tabular}

$60^{\circ}$ まで $15^{\circ}$ ごとに計測するように設定した. その他， 1 方向の夕の変位量を計測するのではなく, 2 方向変位 を計測可能かについて検討を行っている. 詳細は（5) 節にて記述する．また実験機器として，1800万画素デジ タル一眼レフカメラ, 焦点距離 $250 \mathrm{~mm}$ および $600 \mathrm{~mm}$ の カメラレンズ, 反射ターゲットは 1 辺 $55 \mathrm{~mm}$ のものと 1 辺 $110 \mathrm{~mm}$ のものの 2 種類を用意した.

本計測手法の計測精度の評価には，「外的精度」と 「内的精度」を定義している. マイクロメーターにより 与えた変位量を真値と見なすと解析変位量とマイクロメ 一ター変位量の差を誤差と定義できる. 外的精度は，こ の誤差の平均を示し，外的精度が小さいほど計測の「正 確性」が高いことを表す，n 通りのマイクロメーター変 位が実施された場合, 次の式(11)で表される.

$$
(\text { 外的精度 })=\sqrt{\frac{\sum(\text { 計測値 }- \text { 真值 })^{2}}{n}}
$$

また内的精度は，この誤差のばらつき度合いを表し，内 的精度が小さいほど，計測の「精密性」が高いことを示 している.この 2 種類をもって計測精度とした。

\section{（2）撮影距離と計測精度の検証}

撮影距離が大きくなると画像上のターゲット円が小 さくなるため，計測精度は低下していく，そこで，本節 ではターゲットサイズ，カメラレンズの焦点距離を変更 した実験を実施した. 撮影距離は 10〜100m で，正対し た位置から計測を実施した。図-7 に本節での実験結果 を示す. プロットは外的精度を, エラーバーは内的精度 を表している.この結果から，撮影距離が大きくなると 計測精度が低下しているが，ターゲットサイズ，カメラ レンズの焦点距離を大きくすることで計測精度の低下を 抑えていることがわかる．また，撮影距離が $50 \mathrm{~m}$ までで あれば，計測精度を誤差 $0.2 \mathrm{~mm}$ 以内に抑えている．精度 


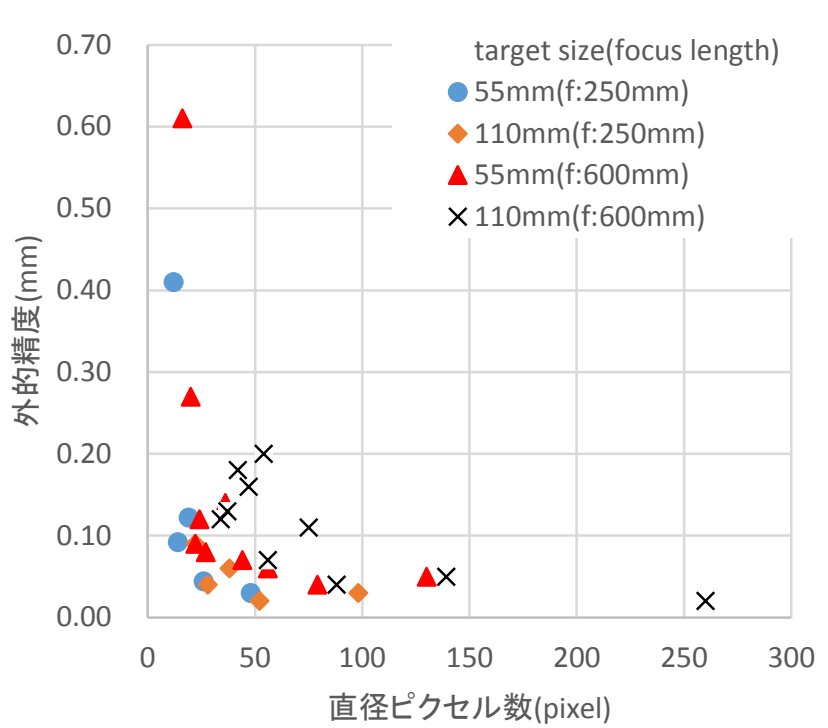

図-8 直径ピクセル数と外的精度

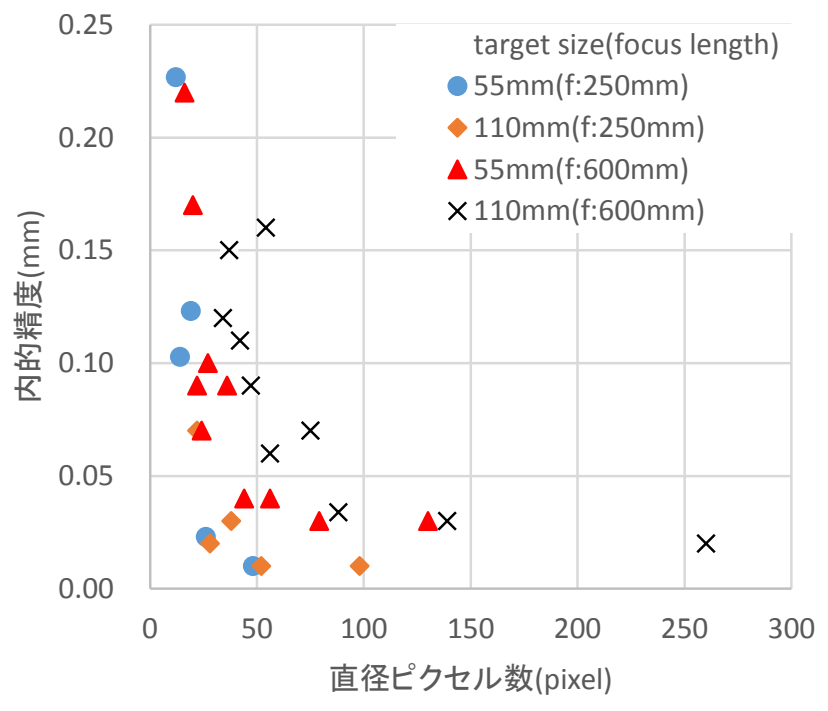

図-9 直径ピクセル数と内的精度

低下要因については，（4）節にて記述する.

\section{（3）撮影角度と計測精度の検証}

次に, 撮影角度と計測精度の関係について検証を実施 した．撮影距離は $10 \sim 100 \mathrm{~m}$ ，撮影角度を $0^{\circ} \sim 60^{\circ}$ まで

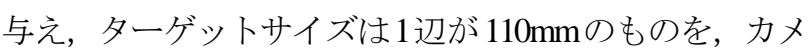
ラレンズの焦点距離は $250 \mathrm{~mm}$ と $600 \mathrm{~mm} の 2$ 種類を用意 し，実験を行った．表-1 および表-2 にその実験結果を 示す. 撮影距離および撮影角度が大きくなると計測精度 は低下していくが，焦点距離 600mm のカメラレンズを 使用した方が，精度の低下は小さい．また撮影距離が $10 \mathrm{~m}$ においては，撮影角度が $60^{\circ}$ においても精度の低下 に大きな変化は見られず，誤差 $0.1 \mathrm{~mm}$ 以下の高精度での 計測が可能であることを示した.
表-3 600mm レンズでの射影変換なしでの計測精度

\begin{tabular}{|c|l|l|l|l|l|l|}
\hline 撮影距離 $(\mathrm{m})$ & 撮影角度 & $0^{\circ}$ & $15^{\circ}$ & $30^{\circ}$ & $45^{\circ}$ & $60^{\circ}$ \\
\hline \multirow{2}{*}{$10 \mathrm{~m}$} & 外的精度 $(\mathrm{mm})$ & 0.01 & 0.01 & 0.05 & 0.08 & 0.20 \\
\cline { 2 - 7 } & 内的精度 $(\mathrm{mm})$ & 0.01 & 0.01 & 0.03 & 0.05 & 0.11 \\
\hline \multirow{3}{*}{$30 \mathrm{~m}$} & 外的精度 $(\mathrm{mm})$ & 0.03 & 0.01 & 0.01 & 0.21 & 0.28 \\
\cline { 2 - 7 } & 内的精度 $(\mathrm{mm})$ & 0.01 & 0.01 & 0.01 & 0.07 & 0.11 \\
\hline \multirow{2}{*}{$50 \mathrm{~m}$} & 外的精度 $(\mathrm{mm})$ & 0.05 & 0.01 & 0.04 & 0.07 & 0.22 \\
\cline { 2 - 7 } & 内的精度 $(\mathrm{mm})$ & 0.03 & 0.01 & 0.03 & 0.03 & 0.11 \\
\hline \multirow{2}{*}{$100 \mathrm{~m}$} & 外的精度 $(\mathrm{mm})$ & 0.08 & 0.09 & 0.06 & 0.09 & 0.17 \\
\cline { 2 - 7 } & 内的精度 $(\mathrm{mm})$ & 0.04 & 0.04 & 0.04 & 0.05 & 0.07 \\
\hline
\end{tabular}
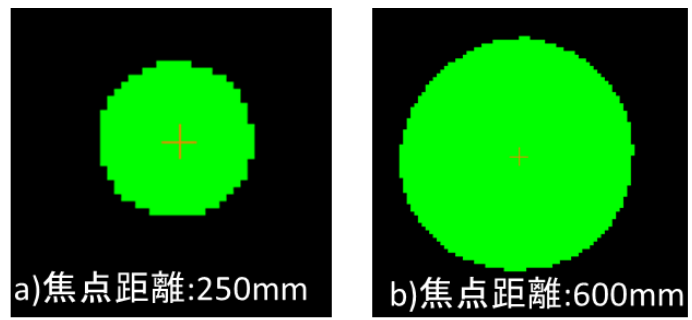

図-10 同じ撮影距離（50m）での焦点距離の違いによる解像 度の違い

\section{（4）計測精度の低下要因}

以上の実験結果を踏まえ，本節では計測精度の低下要 因について検討を行った. 計測精度の低下要因として考 えられる指標として, 直径ピクセル数がある. 直径ピク セル数とは，画像上のターゲット円のスケールのことを 指寸. 図-8 および図-9 に直径ピクセル数と計測精度の 関係を表したグラフを示寸. 直径ピクセル数が約 50 ピ クセルを下回ると急激に誤差が増大している．この原因 として 2 つ考えられる. 1 つ目はピクセル数の減少に伴 う重心座標の読み取り誤差が大きくなることである. 図 -10 に同じ撮影距離で焦点距離を変更した際の画像の解 像度の違いを示寸，撮影距離が大きくなると，ターゲッ 卜円が小さくなるためにその解像度が低下し, 円の形状 を保つことができず，ターゲット円の重心座標の読取誤 差が大きくなり，計測誤差が大きくなったと考えられる. そのため，ターゲットサイズおよびカメラレンズの焦点 距離を大きくすることにより, 解像度の低下を抑え, 計 測精度の低下を抑えられている. その他, 画像の解像度 低下を抑える方法として, カメラの解像度を上げること によっても画像上のターゲット円の解像度の低下を抑え ることができることから，計測精度が向上すると考えら れる. 2 つ目は, 射影変換を行うことによりターゲット 円の重心座標の読み取り誤差が伝播され, 計測誤差がさ らに拡大寸ることである．重心座標の読み取り誤差が大 きくなると, 誤差伝播によりさらに誤差が拡大されるた めに, 計測精度が低下したと考えられる. そのため, 解 析処理において射影変換処理を行わない，すなわち画像 の正対化を行わない計測を実施した。その結果を表-3 に示寸。この結果から，撮影距離が $100 \mathrm{~m}$ においても撮 


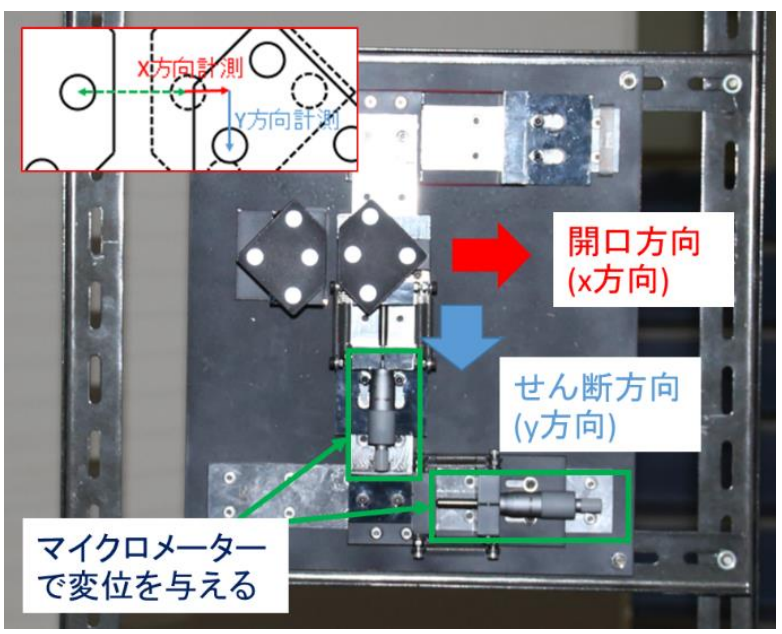

図-11 2万向変位実験装置

表-4 2万向変位実験の実験結果

\begin{tabular}{|c|c|c|} 
& \multicolumn{2}{c|}{$x$ 方向 } \\
\hline 撮影距離 $(\mathrm{m})$ & 外的精度 $(\mathrm{mm})$ & 内的精度 $(\mathrm{mm})$ \\
\hline $1 \mathrm{~m}$ & 0.00 & 0.00 \\
\hline $3 \mathrm{~m}$ & 0.02 & 0.02 \\
\hline $5 \mathrm{~m}$ & 0.06 & 0.03 \\
\hline \multicolumn{2}{|c|}{$\mathrm{y}$ 方向 } \\
\hline 撮影距離 $(\mathrm{m})$ & 外的精度 $(\mathrm{mm})$ & 内的精度 $(\mathrm{mm})$ \\
\hline $1 \mathrm{~m}$ & 0.01 & 0.00 \\
\hline $3 \mathrm{~m}$ & 0.03 & 0.00 \\
\hline $5 \mathrm{~m}$ & 0.01 & 0.01 \\
\hline
\end{tabular}

影角度が $30^{\circ}$ 以内であれば計測精度が誤差 $0.1 \mathrm{~mm}$ 以下と なった. しかし, 表-2 と比較すると, 撮影距離が短く 撮影角度が大きくなった場合には，射影変換処理を行う 解析方法での計測結果のほうが計測精度が向上している ことから，撮影距離によって計測手法を変更する必要が ある．すなわち，撮影距離が短い場合には射影変換処理 を実施した解析手法によって計測を行い，撮影距離が大 きい場合は射影変換処理を行わない解析による計測を適 用する.

\section{(5) 2 方向の変位計測実験}

現場での実用性を高めるため，2 方向の変位を同等の 精度で計測可能かについて検証を行った．実際のコンク リート構造物に発生したひびわれは，開口方向と同時に せん断方向にも進行する可能性が考えられる．従来のひ びわれの変位量計測は，2 点間距離の計測により開口量 とすることが多い. 本手法はターゲット円の 2 次元重心 座標を取得するという特徴から，ひびわれを $\mathrm{x}, \mathrm{y}$ 座標 の 2 万向に分けて検出することが可能かについて検証を 行った.

本実験では，図-11 に示すような $\mathrm{x}$ 方向（開口方向） および $\mathrm{y}$ 方向（せん断方向）に変位を与えることができ

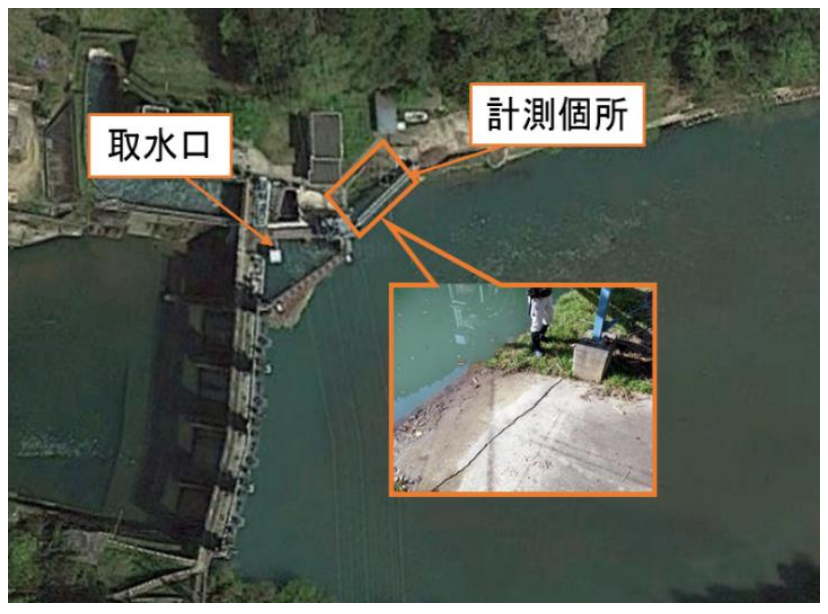

図-12 計測個所の状況

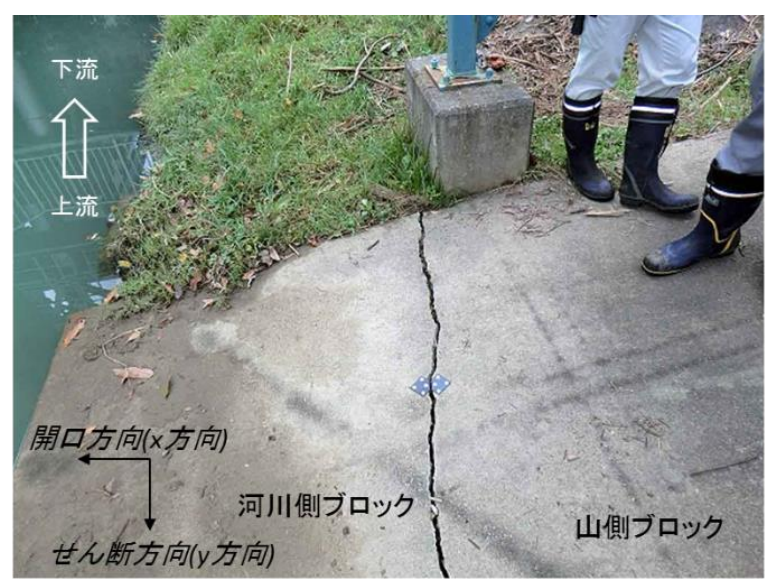

図-13＼cjkstart開口方向とせん断方向の向き

る装置を用いて, 反射ターゲットの一方を固定し, マイ クロメーターを用いて $\mathrm{x}, \mathrm{y}$ 方向にそれぞれ $0.2 \mathrm{~mm}$ ずつ $1.0 \mathrm{~mm}$ まで等しく変位を与え実験を行った，撮影距離は $1 \mathrm{~m} ， 3 \mathrm{~m} ， 5 \mathrm{~m}$ でターゲットに正対した位置から計測を行 った. なお，（2）節および（3）節において $100 \mathrm{~m}$ まで ターゲットの認識および計測が可能であることが確認さ れているため，本実験では近距離での計測で 2 方向の変 位計測を検証した.レンズの焦点距離は $50 \mathrm{~mm}$ のものを 使用した。表-4 に実験結果を示す。実験を行った撮影 距離すべてにおいて外的精度，内的精度ともに誤差 $0.1 \mathrm{~mm}$ 以内の高精度での計測を行うことが可能であった。 これらの結果より，本計測手法の 2 方向変位計測の実用 性を示した.

\section{4. 現場計測における本計測手法の検証}

実際のコンクリート構造物の健全性を評価するために, ひびわれの変位量の計測を実構造物に対して実施し，本 計測手法の有用性を検証した，本章では 2 例紹介する. 


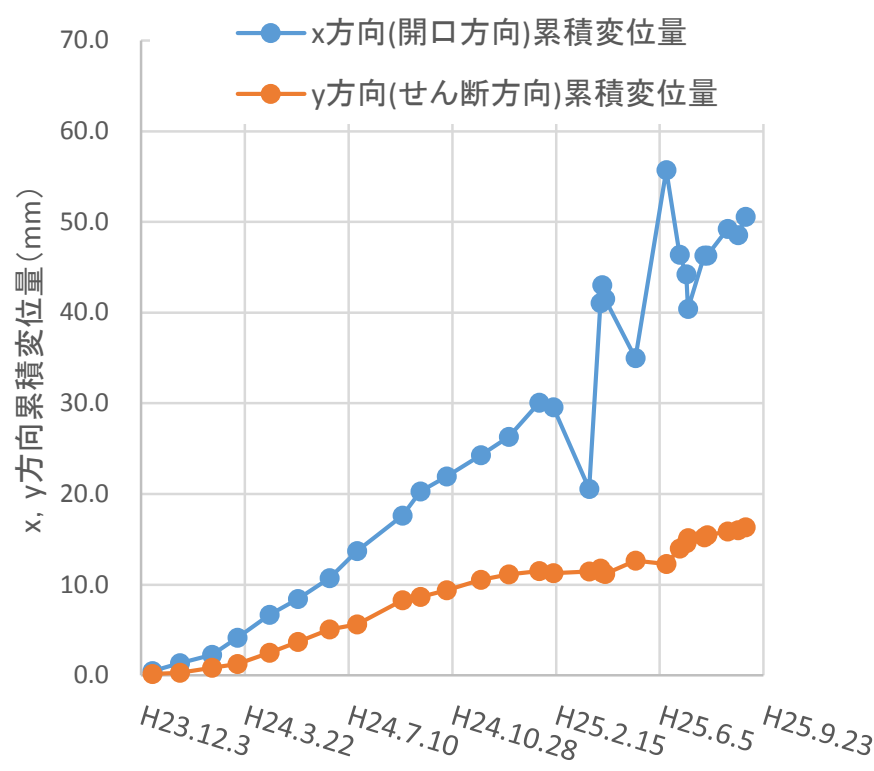

図-14 ひびわれの2方向変位計測結果

事例 1 は撮影距離が $1 \mathrm{~m}$ の近接計測，事例 2 は撮影距離 $50 \mathrm{~m}$ の遠距離計測で解析手法については各節で記述寸る. ターゲットを設置する際には，コンクリート表面を洗浄 した上で接着剤にて接着，固定した.

\section{(1) 計測事例 1 (近接計測)}

対象とした構造物は，電力施設（電源開発（株）の管 理施設）であるダム貯水池の右岸側に位置するコンクリ ート製スロープである. 図-12 に計測個所の状況を示す。 平成 23 年度の出水時にスロープの護岸が洗掘で沈下し たことにより，ひびわれが発生した．また計測点は貯水 池の水位が上昇すると水没してしまい，ゲージの設置が 困難となったため，本手法を適用して計測を行った．夕 一ゲット設置はひびわれに直交する方向を $\mathrm{x}$ 方向，その 直交方向を $\mathrm{y}$ 方向とした. 図-13 に本構造物における開 口方向およびせん断方向の向きを示す. 開口方向（x 方 向）はターゲットが開く方向を正，せん断方向（y 方向） はターゲットが上流側に動く方向を正としている.

計測は平成 23 年 12 月に初期值取りを行い，平成 25 年 9 月まで計 31 回の計測を実施した。撮影間隔は約 1 ヶ月 毎である. 撮影距離は $1 \mathrm{~m}$ であるため, 射影変換処理を 実施する解析手法により計測を行った。横軸に計測日， 縦軸に 2 方向別の累積変位量をとったグラフを図-14に 示寸. このグラフから $\mathrm{x}$ 方向, $\mathrm{y}$ 方向ともに累積変位量 が増加していることから，このひびわれは進行性のある ものであることがわかる：ひびわれ開口方向 ( $\mathrm{x}$ 方向) の月間変位量は $2.39 \mathrm{~mm} ，$ せん断方向（y方向）の月間変 位量は $0.77 \mathrm{~mm}$ であり, 開口方向に卓越したひびわれで あることがわかる。このようにひびわれが進行した原因 として, 貯水池護岸の洗掘が考えられる. 対象となった

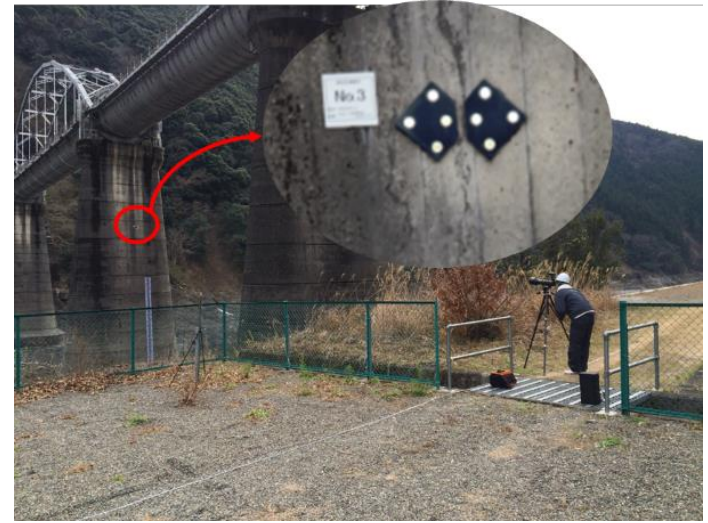

図-15 計測個所の概要

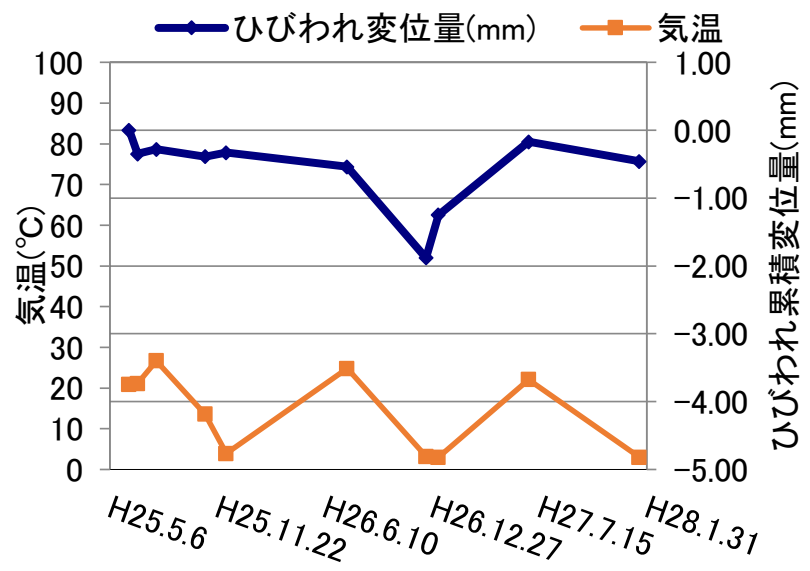

図-16 現場計測におけるひびわれの変位量

貯水池は運用水深が 5 6m と浅い．そのため運用時の流 速により, 護岸の洗掘により沈下が進み, ひびわれが進 行したと考えられる.さらに，せん断方向成分が上流側 に進行しているのは, 護岸の洗掘が上流側から進行して いるためであると考えられる. 平成 25 年 2 月以降には 開口方向の累積変位量にばらつきが認められるが，これ は構造物の崩壊する可能性があると考えられたため, 現 地では立入禁止措置を講ずるなどの対策を実施した。こ の後, 貯水池側のブロックは, 平成 25 年 9 月に流出し ている.このように定量的な計測を実施することにより， 崩壊発生のリスク評価に寄与することができ，また2 方 向の変位解析を行うことで挙動のメカニズムも推定する ことができ，その実用性を示した。

\section{(2) 計測事例 2（遠距離計測）}

続いて計測対象とした構造物は，電力設備（電源開発 （株）の管理施設）である橋梁のコンクリート橋脚部分 に発生したひびわれである. 周辺は斜面崩壊や深層崩壊 が多く発生する個所であり，それらによる土石流が橋梁 
に対して影響を与えることが想定された．また計測対象 点は直接ゲージを設置したり，直接スケールを当てるこ とにより計測することが困難であることから，本計測手 法により計測を実施し，データの取得を継続して行って いる. 計測対象となったターゲットは図-15 に示すよう な川中の橋脚に設置されており, 計測するひびわれは構

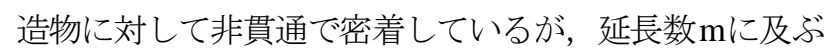
ものである．計測は約 3 年間で不定期に実施し，撮影距 離は $50 \mathrm{~m}$ であるため, 射影変換処理を行わない解析方法 により行った. 横軸に計測日, 縦軸に本手法でのひびわ れ累積変位量をとったグラフを計測地点における気温デ 一タとともに図-16 に示寸．これを見ると，初期值から 収縮方向への変位が見られるが，初期值から拡大方向一 の変位は見られない．また温度変化との相関についても 認められず，本計測対象点は安定した状態であると判断 した. 今後も不定期に計測を実施し，地震等の災害時に 計測を行うことで，ひびわれの挙動を把握することとし た.

\section{5. まとめ}

本研究は，デジタル画像を用いたひびわれの変位量を 計測する手法を構造物のモニタリング技術として適用す るため, 室内実験から精度検証を行い, 実際のコンクリ 一ト構造物に適用した。本計測手法の特徵は, 反射ター ゲットを計測対象点に設置し，任意の撮影位置から計測 を行うという簡易な手法でありながら，高精度でひびわ れの変位量を計測することを可能とするものである，以 下に得られた結論を示す.

1)撮影距離が大きくなるにしたがって計測精度は低下す るが, ターゲットサイズ, カメラレンズの焦点距離を 大きくすることにより, 精度の低下を抑えることがで きる.

2)計測精度の低下要因について検討を行ったところ，射 影変換処理による誤差の伝播が考えられた。 そして射 影変換処理を行わないことにより計測精度の低下を抑 え, 高精度での計測結果を得た。

3)撮影距離によって解析手法を変更することにより, 高 精度での計測が可能である.

4)ターゲットの 2 次元座標を算出するという本計測手法 の特徴を活かし，ひびわれの開口方向とせん断方向の 2万向の変位を検出することを可能とした.

5)実際の構造物に適用した結果, 2 方向変位を計測する ことで,ひびわれ進行の方向を確認した．また遠距離 計測においても，ひびわれ特性を十分に確認できる高 精度での計測が可能である.
今回の実験結果から, 誤差要因として射影変換処理に おける誤差伝播について検討を行ったが，これは変換処 理時におけるキャリブレーションの問題など，さらなる 検討が必要であると考えられる. 今後は，1枚の画像よ り反射ターゲットを自動認識し，多点計測を可能にする プログラムの作成．また計測現場での長期的な計測を実 施して本計測手法の有用性を確認していく.

謝辞 : 本研究を遂行するにあたり, 現場での計測や解析 にご協力いただいた電源開発株式会社西日本支店の関係 者各位および高精度化に関して多大なご指導・ご協力を いただいた電源開発株式会社秦野輝儀氏に深く謝意を表 します。

\section{参考文献}

1) 国土交通省：国土交通白書 2016，p.38，2016.

2）山田隆昭, 佐野信夫, 馬場弘二, 吉武勇, 中川浩二, 西村和夫：トンネル覆エコンクリートの定量的な健 全度評価基準, 土木学会論文集, 第 63 巻, 1 号, pp.86-96, 2007.

3) 金澤涁, 西山哲, 矢野隆夫, 菊地輝行 : 構造物の維 持管理のためのひびわれ幅の画像計測手法の研究, 岩盤力学に関するシンポジウム講演集, pp332-336, 2012.

4) 木元亮輔, 藤田悠介, 河村圭, 浜本義彦: 画像処理 によるコンクリート構造物のひびわれ計測の実用化 に関する基礎研究, $26^{\text {th }}$ Fuzzy System Symposium Hiroshima 2010.

5) 菊地輝行, 秦野輝儀, 盇阪知広, 西山哲: デジタル 画像を利用したひび割れ幅計測手法の研究, 第59回 地盤工学シンポジウム, 平成 26 年度論文集, pp.4550, 2014.

6) 日本コンクリート工学会 : コンクリートのひび割れ 調查, 補修・補強指針-2013-, p.121，pp.126-142， 日本コンクリート工学会, 2013.

7) 菊地輝行, 秦野輝儀: 画像計測法のクラック幅計測 一の適用, 日本応用地質学会研究発表会講演論文集, VI-502, 2014.

8) Fraser, C.S. : High Acuracy Ground Surface Displacement Monitoring, Photogrammetric Record, Vol.14, No.81, pp.505-521, 1993.

9) Franklin, J.A. and Dussault, M.B.: Rock Engineering, p.296, Mc Graw Hill, 1989.

10）龍明治, 大西有三, 西山哲, 中井卓巳 : デジタル画 像計測による斜面モニタリングシステムの研究, 地 盤工学ジャーナル, Vol.3, No.2, pp109-119, 2007.

11) 村井俊治, 近津俊文監修, 日本写真測量学会, 動体 計測研究会編 : デジタル写真測量の理論と実践, pp.34-43, 日本測量協会, 2004.

12) Trinder, J.C., : Precision of Target Location, Photogrammetric Engineering and Remote Sensing, Vol.55, No.6, pp.883-886, 1989.

(2016. 10.27 受付) 


\title{
A STUDY ON DIGITAL PHOTOGRAMMETRY FOR MONITORING INFRASTRUCTURES
}

\begin{abstract}
Akihisa HIROTA, Satoshi NISHIYAMA and Teruyuki KIKUCHI
This paper presents a study on monitoring method of crack width on concrete structures using digital photogrammetry. In this measurement procedure, the reflective targets are installed at measurement points around the crack as the gauges, and the deformation of crack width is calculated from one image taken from arbitrary camera positions. In this paper, we verify the relation between the accuracy/precision and the distance/angle of photographic positions from the targets in experiments, and the results showed that it was possible to measure the displacement of crack about $0.1 \mathrm{~mm}$ at $100 \mathrm{~m}$ and 30 degree photographic angle. Moreover, application of this method to measuring crack changes on actual concrete structures showed that it was possible to monitoring of the structures easily by using this method.
\end{abstract}

